\title{
Aplikasi Teknologi Near Infrared Reflectance Spectroscopy Dengan Metode Partial Least Square Untuk Prediksi Kadar Patchouli Alkohol Minyak Nilam
}

\author{
(The Technology Application Near Infrared Reflectance Spectroscopy With Partial Least \\ Square Method (PLS) To Prediction Patchouli Alcohol Content In Patchouli Oil)
}

\author{
Sry Afrita Fitia ${ }^{1}$, Rita Khathir ${ }^{1}$, Zulfahrizal ${ }^{1}$ * \\ ${ }^{1}$ Program Studi Teknik Pertanian, Fakultas Pertanian, Universitas Syiah Kuala \\ *Corresponding author: zulfahrizal@unsyiah.ac.id
}

\begin{abstract}
Abstrak. Minyak nilam merupakan salah satu jenis dari minyak atsiri yang dapat digunakan sebagai bahan baku dalam industri parfum, kosmetik serta untuk pengobatan. Minyak nilam mengandung patchouli alkohol yaitu penyusun utama yang digunakan sebagai indikator untuk mengetahui kualitas dari minyak nilam. Tujuan dari penelitian ini yaitu untuk mengkaji kemampuan teknologi near infrared reflectance spectroscopy (NIRS) dengan metode partial least square (PLS) dalam memprediksi kadar patchouli alkohol pada minyak nilam. Hasil penelitian menunjukkan bahwa PLS mampu memprediksi kadar patchouli alkohol dengan menghasilkan model yang tergolong good model performance. Peningkatan performa kinerja PLS terbaik diperoleh pada penggunaan pretreatment standart normal variate dengan nilai RPD 2,83 dengan karakteristik model nilai koefisien korelasi (r) sebesar 0,93, nilai koefisien determinasi $\left(\mathrm{R}^{2}\right)$ 0,86 dan nilai error (RMSEC) sebesar 4,11.
\end{abstract}

Kata Kunci: Minyak Nilam, Patchouli Alkohol, Partial Least Square

\begin{abstract}
Patchouli oil is one type of essential oil that is used as a raw material in the perfume, cosmetic and medical industry. Patchouli oil is categorized in with the main component of essential oil patchouli alcohol used as an indicator to determine the quality of patchouli oil. The purpose of this research is to assessing technological capabilities of near infrared reflectance spectroscopy (NIRS) with method partial least square (PLS) to predict patchouli alcohol content in patchouli oil. The results showed that PLS be able to predict patchouli alcohol levels by producing a model that is classified as good model performance. The best improved performance in the pretreatment PLS performance was by using standard normal variate as pretreatment with RPD value about 2,83 correlation coefficient (r) 0.93, the coefficient of determination $\left(\mathrm{R}^{2}\right)$ at 0.86 , and (RMSEC) about 4.11 .
\end{abstract}

Keywords: Patchouli Oil, Patchouli Alcohol, Partial Least Square

\section{PENDAHULUAN}

Indonesia merupakan negara yang berpotensi sebagai penghasil minyak atsiri yang cukup besar. Beberapa jenis tanaman penghasil minyak atsiri diantaranya yaitu nilam, cengkeh, kayu manis, pala, sereh wangi, akar wangi dan lain sebagainya. Tanaman nilam pada umumnya telah dibudidayakan di Indonesia yaitu nilam Aceh (Pogostemon coblin Benth) dan nilam Jawa (Pogostemon heyneanus Benth). Minyak nilam merupakan salah satu jenis dari minyak atsiri yang dapat digunakan sebagai bahan baku dalam industri parfum, kosmetik serta untuk pengobatan Minyak nilam telah menyumbang lebih dari 50 persen ekspor minyak atsiri Indonesia, sehingga diharapkan menjadi komoditas unggulan di pasar ekspor (Idris et al., 2014). Minyak nilam mengandung patchouli alkohol yaitu penyusun utama dan digunakan sebagai indikator untuk mengetahui kualitas dari minyak nilam. Tanaman nilam ini untuk keseluruhan mengandung minyak atsiri tetapi kandungan minyak atsiri yang terbesar terdapat pada bagian daun (Syauqiah, 2008).

Tanaman nilam (Pogostemon coblin Benth) merupakan salah satu tanaman penghasil minyak atsiri yang penting, dikenal dengan nama patchouli oil. Tanaman ini mengandung komponen utama patchouli alkohol (PA), yaitu senyawa kelompok seskuiterpen dengan rumus melekul $\mathrm{C}_{15} \mathrm{H}_{26} \mathrm{O}$. Adapun kadar patchouli alkohol yang tinggi dalam minyak nilam memberikan 
artian bahwa akan semakin baik kualitas minyak tersebut. Patchouli alkohol berfungsi sebagai bahan pengikat wewangian agar aroma keharumannya bertahan lama. Penyebab aroma wewangian dapat bertahan lama ialah sifat dari minyak nilam ialah sebagai pengikat bau wangi bahan pewangi lain atau fiksatif sekaligus dapat membentuk bau yang lembut dalam suatu campuran (Sastrohamidjojo, 2002). Biasanya untuk mengetahui kandungan patchouli alkohol minyak nilam dilakukan uji laboratorium dimana pengujian ini menggunakan metode dan bahan kimia tertentu sehingga membutuhkan waktu yang cukup lama dan biaya yang mahal. Hal ini tentunya menjadi masalah tersendiri bagi pelaku yang bergerak di perdagangan minyak nilam.

Saat ini teknologi inframerah sudah mulai dikembangkan untuk menguji kualitas minyak nilam khususnya patchouli alkohol. Terdapat penelitian yang dilakukan oleh Abdurahman dan Sundarajan (2019) menggunakan middle infrared reflectance spektroscopy untuk menguji patchouli alkohol dan penelitian yang dilakukan oleh Zulfahrizal et al, (2019) melakukan penelitian untuk pengujian kadar patchouli alcohol (PA) pada minyak nilam Aceh yang menunjukkan bahwa teknologi NIRS mampu menduga kandungan kadar patchouli alkohol dengan menggunakan metode partial least squares. Kemudian ada juga penelitian yang dilakukan oleh Burahman (2020) yang menggunakan teknologi near infrared reflectance spektroscopy dengan metode principal component regression (PCR) untuk menguji patchoui alkohol. Oleh karena itu dalam penelitian ini mencoba untuk mengembangkan model pendugaan yang baru dengan menggunakan metode partial least square dan menggunakan pretreatment detrending dan standart normal variate.

\section{Alat dan Bahan}

\section{METODE PENELITIAN}

Alat yang digunakan pada penelitian ini adalah GCMS, Self developed FT-IR IPTEK T1516, botol kaca $5 \mathrm{ml}$, timbangan, pipet ukur, gelas reaksi dan Unscrambler software ${ }^{\circledR} \mathrm{X}$ version 10.5. Bahan yang digunakan pada penelitian adalah minyak nilam Aceh hasil fraksinasi dengan kadar patchouli alkohol yang berbeda.

\section{Perlakuan Sampel}

Minyak nilam Aceh yang digunakan adalah minyak yang sudah difraksinasi di Atsiri Research Center Universitas Syiah Kuala Banda Aceh, yaitu minyak fraksi berat dua jenis (M1 da M2) dan minyak fraksi ringan satu jenis (M3). Uji kromatografi gas (GCMS) dilakukan untuk mendefinisikan kandungan patchouli alkohol untuk ketiga minyak fraksinasi tersebut. Lalu ketiga jenis minyak ini dicampur untuk mendapatkan tiga jenis yakni minyak destilat satu yang memiliki kadar patchouli alkohol antara 0-20\% dengan jumlah sampel sebanyak tujuh buah, destilat dua memiliki kadar patchouli alkohol 21-32\% dengan jumlah enam buah, dan destilat tiga memiliki kadar patchouli alkohol antara 33-50\% dengan jumlah tujuh sampel.

\section{Uji Kadar Patchouli Alkohol Laboratorium}

Pengujian kadar patchouli alkohol menggunakan metode Kromatografi gas (GCMS) yang digunakan dalam kimia analitik untuk memisahkan dan menganalisis senyawa pada minyak nilam yang dapat menguap tanpa dekomposisi. Kromatografi gas (GCMS) dapat digunakan untuk pengujian kemurnian zat tertentu, atau memisahkan komponen yang berbeda dari campuran (jumlah relatif komponen tersebut juga dapat ditentukan). Juga dapat digunakan dalam mengidentifikasi suatu senyawa. Cara kerja GCMS menurut Darmapatni et al. (2016) adalah 
komponen yang telah dilarutkan dengan pelarut kemudian diinjekan di injeksikan dan di bawa oleh carier gas supplay melewati kolom yang telah dipanaskan terlebih dahulu memakai oven. Sehingga komponen tersebut terbaca di detector dan direkam dalam recorder. Disini akan didapatkan pembacaan berupa peak area yang menunjukkan perprosentase area dari komponen yang dianalisa prosentase area didapatkan dari pembacaan grafik. Grafik berupa peak pada rentang waktu tertentu menunjukkan kecepatan migrasi komponen dan setiap komponen punya rentang waktu tertentu.

\section{Pengaturan Alat NIRS}

Adapun alat yang digunakan untuk mendapakan spektrum NIRS minyak nilam yaitu self developed FT-IR IPTEK T-1516. Spektrum NIRS yang dihasilkan oleh alat ini secara umum sudah sesuai standar alat NIRS komersial. Akan tetapi perlu diperhatikan pengaturan frekuensi dan kebutuhan energi (optical gain, number of scans dan resolution) dalam proses pengambilan spektrumnya agar dihasilkan spektrum yang baik. Adapun alat self developed FT-IR IPTEK T1516 dapat meradiasikan gelombang cahaya dengan kisaran panjang gelombang antara $1000 \mathrm{~nm}$ sampai $2500 \mathrm{~nm}\left(4000-10.000 \mathrm{~cm}^{-1}\right)$ serta dikontrol oleh perangkat lunak Thermo Operation®. Spektrum NIRS bisa didapatkan didapatkan dengan konfigurasi alur kerja ala (workflow) yang dibangun dengan menggunakan perangkat lunak terintegrasi Thermo Operation $®$. Pembuatan workflow dilakukan untuk mengatur alat dalam bekerja. Pengaturan alat NIRS diatur dengan 64 scans, resolution $2.0 \mathrm{~cm}^{-1}$ dan gain $4 \mathrm{x}$ sehingga dapat mengakuisisi spektrum diffuse reflectance sampel, lalu merata-ratakan hasilnya dan menyimpan hasil pemindaian kedalam dua bentuk file yaitu *.SPA dan *.CSV. Hasil yang didapatkan dari transpormasi nilai reflektan ke absorbance yang diubah ke dalam bentuk log (1/R) (Zulfahrizal et al., 2017).

\section{Pemeriksaan Data Outlier (PCA dan Hotteling $T^{2}$ Ellipse)}

Data outlier di remove dengan metode principal component analysis (PCA) dan hotteling T2 ellipse yang merupakan cara untuk menganalisa data pencilan. Data yang diambil adalah data yang berada di dalam garis ellipse, apabila data berada di luar garis ellipse, maka data tersebut ditandai sebagai data pencilan (outlier) dan dihilangkan (remove) agar hasil prediksi lebih akurat (Cozolino et al., 2011).

\section{Perlakuan Pretreatment}

Data penelitian selanjutnya diberikan pretreatment spektrum. Menurut (Mouazen et al., 2010) dilakukan terlebih dahulu koreksi spektrum agar dapat membangun model prediksi spektrum NIR dengan tujuan menghilangkan noise pada spektrum sampel sehingga hasil dari prediksi lebih akurat. Pada penelitian ini digunakan pretreatment yaitu de-trending (DT) dan standart normal variate (SNV). Model prediksi yang digunakan untuk memprediksi kadar patchouli alkohol minyak nilam adalah metode partial least square.

\section{Pembuatan Model Kalibrasi dan Evaluasi Keakuratan Model}

Kadar patchouli alkohol diprediksi dengan cara membangun model PLS berdasarkan data dari spektrum NIR (Variable X) dan data nilai patchouli alkohol dari laboratorium (Variable Y). Evaluasi keakuratan model kalibrasi dilakukan dengan cara melihat parameter statistik meliputi; koefisien korelasi (r), koefisien determinasi $\left(\mathrm{R}^{2}\right)$, root mean square error (RMSE), residual predictive deviation Index (RPD), serta jumlah latent variable (LV). 


\section{HASIL DAN PEMBAHASAN}

\section{Spektrum Mentah Minyak Nilam}

Spektrum mentah adalah hasil dari pengambilan spektrum near infrared reflectance (NIR) pada selang panjang gelombang $1000-2500 \mathrm{~nm}$. Pada penelitian ini tidak menggunakan panjang gelombang 780-999 nm dikarenakan pada panjang gelombang dibawah $1000 \mathrm{~nm}$ cenderung tidak memberikan informasi yang dibutuhkan untuk pengukuran spektra dengan alat NIRS dalam mendeteksi kandungan kimia dari bahan, karena bersinggungan dengan cahaya tampak. Pada panjang gelombang tersebut dapat dilihat spektrum dengan beberapa puncak dan lembah spektrum. beberapa puncak dan lembah yang terbentuk pada spektrum yang dihasilkan sebagai tanda keberadaan kandungan zat kimia pada bahan dengan panjang gelombang tertentu. Penyerapan panjang gelombang oleh kandungan kimia tertentu ditunjukkan dengan terjadinya puncak dan lembah gelombang pada kurva absorbsi near infrared reflectance, semakin banyak interaksi gelombang NIR dengan kandungan kimia bahan, maka semakin banyak puncak dan lembah gelombangnya. Komponen kimia mempengaruhi puncak dan lembah pada spektrum near infrared reflectance (NIR) didalam bahan yang dianalisis. Spektrum mentah minyak nilam fraksinasi dapat dilihat pada Gambar 1.

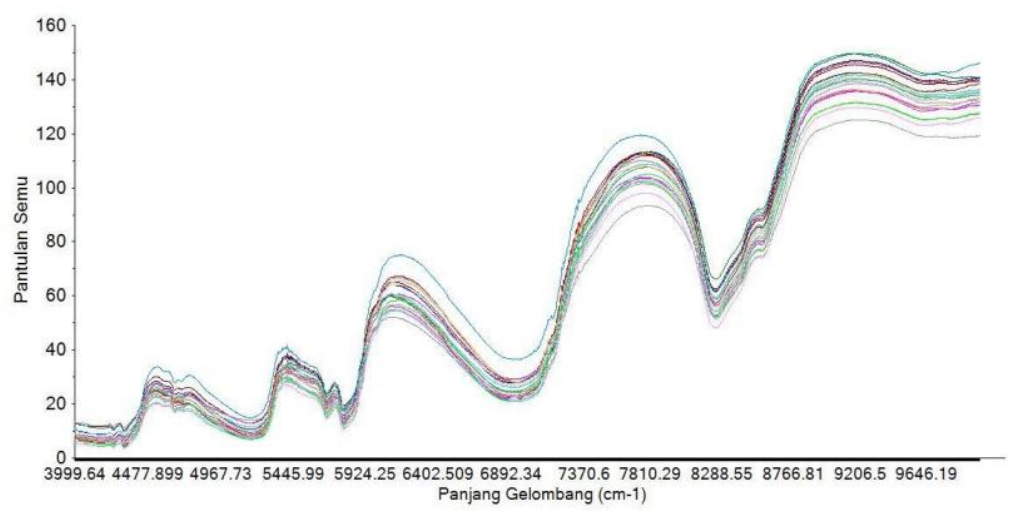

Gambar 1. Spektrum Mentah Minyak Nilam Fraksinasi

Spektrum pada Gambar 1 terlihat memiliki noise. Noise (gangguan) biasanya disebabkan oleh faktor internal dan eksternal. Faktor internal dapat disebabkan oleh alat yang berlebihan panas saat pengembalian spektrum. Sedangkan faktor eksternal dapat disebabkan oleh lingkungan yaitu seperti pengaruh suhu dan cahaya dalam ruangan pada saat pengambilan data. Noise yang terdapat pada minyak nilam dapat diidentifikasikan melalui keberadaan getaran yang banyak pada suatu tempat dan bentuk spektrum yang tidak rapat. Spektrum yang terdapat noise dapat diatasi dengan melakukan pengolahan awal data spektra.

\section{Penerapan PCA dan Hotteling $T^{2}$ Ellipse untuk Memeriksa Data Outlier}

Data outlier atau data pencilan adalah suatu data yang berbeda dengan data-data lainnya yang dapat mengganggu data pendugaan pada saat kalibrasi spektrum. Data pencilan dideteksi menggunakan metode principal component analysis (PCA) dan hotteling $T^{2}$ ellipse. Data yang tergolong ke dalam pencilan merupakan data yang berada di luar garis ellipse. Adapun pemeriksaan data pencilan dapat dilihat pada Gambar 2. 


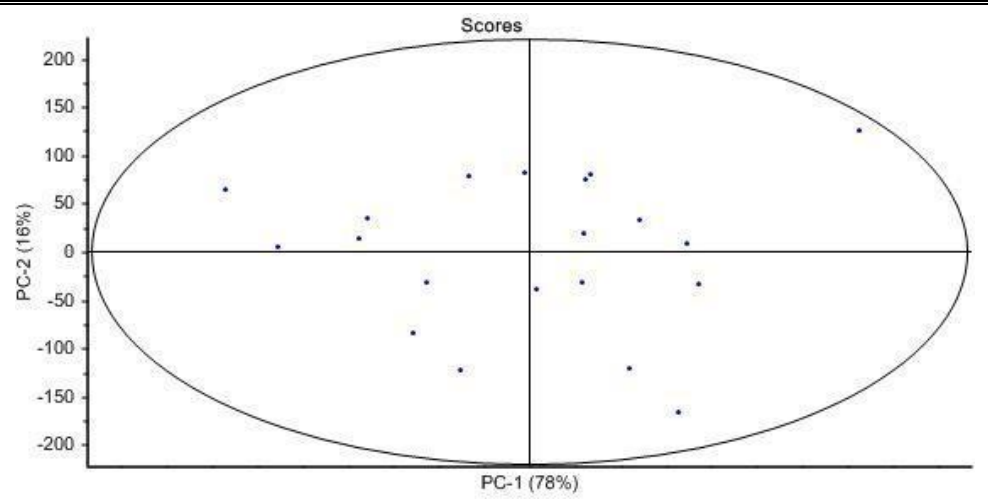

Gambar 2. Pemeriksaan Data Outlier dengan Metode PCA dan Hotteling $T^{2}$ Ellipse

Gambar 2 menjelaskan bahwa tidak ada data yang berada di luar garis ellipse. Penelitian ini sesuai dengan penelitian yang dilakukan oleh Burahman (2020), bahwa tidak ada yang tergolong ke dalam data pencilan atau data yang berada di luar garis ellipse. Oleh karena itu analisa dapat dilanjutkan ke tahap selanjutnya yaitu pembuatan model pendugaan patchouli alkohol menggunakan metode partial least square.

\section{Acuan Pengukuran Data Kalibrasi}

Acuan Pengukuran data kalibrasi berfungsi untuk membantu mempermudah dalam proses analisa model kalibrasi yang akan dibuat nantinya. Model kalibrasi digunakan dengan tujuan membangun model persamaan matematik yang dapat digunakan untuk dapat memprediksi kandungan kimia bahan pangan tanpa harus melakukan pengukuran langsung secara destruktif yang dapat merusak bahan. Proses kalibrasi menggunakan 20 sampel minyak nilam. Acuan pengukuran data yang perlu dibuat adalah seperti selang antar sampel dan standar deviasi (SD) sampel yang dapat dilihat pada Tabel 1 .

Tabel 1. Acuan Pengukuran Data Kalibrasi

\begin{tabular}{lcccc}
\hline Bagian & Jumlah Data & \multicolumn{3}{c}{ Parameter Statistik Deskriptif } \\
\hline \multirow{2}{*}{ Sampel } & 20 & Maksimum & $\frac{\text { Minimum }}{7,09}$ & Standar Deviasi \\
& 20,33 & & 11,64 \\
\hline
\end{tabular}

Tabel 1 dapat dilihat data memiliki keragaman yang cukup besar, bahwa dengan keragaman yang cukup besar ini menunjukkan bahwa persiapan sampel dengan 20 sampel ini sudah cukup bagus dengan nilai standar deviasi 11,64 serta nilai maksimum sebesar 45,33 dan nilai minimum sebesar 7,09 yang diperoleh dari hasil analisis laboratorium.

\section{Pendugaan Kadar Patchouli Alkohol Minyak Nilam Menggunakan PLS Tanpa Pretreatment}

Data spektrum yang dihasilkan dari spektrum mentah yang belum diperbaiki menghasilkan nilai koefisien korelasi (r) sebesar 0,79. Menurut Safitri (2016), apabila nilai koefisien korelasi (r) yang didapatkan mendekati 0,79 maka menunjukkan keeratan hubungan sangat kuat. Nilai koefisien determinasi $\left(\mathrm{R}^{2}\right)$ sebesar 0,63. Menurut Karoui et al. (2006) nilai 0,63 menunjukkan prediksi kurang baik dikarenakan hanya 0,50-0,65 variable Y yang dapat dijelaskan oleh variable X. Nilai root mean square error calibration (RMSEC) yang didapatkan yaitu 6,90 lebih rendah dari nilai standar deviasi dan latent variable yang digunakan adalah 4. Menurut Zulfahrizal et al. (2020) apabila nilai root mean square error calibration (RMSEC) 
lebih kecil dari nilai standar deviasi berarti data tergolong bagus dan nilai latent variable yang baik yaitu dibawah 9 dengan ketentuan semakin kecil semakin bagus. Nilai residual predictive deviation (RPD) yang didapatkan adalah 1,68. Menurut Nicolai et al. (2007) apabila nilai RPD yang didapatkan 1,68 maka digolongkan dalam prediksi masih kasar (sufficient performance). Pada penelitian ini nilai root mean square error calibration (RMSEC) masih bisa diturunkan dan nilai residual predictive deviation (RPD) masih bisa ditingkatkan sehingga selanjutnya dilakukan pretreatment terhadap spektrum mentah. Selengkapnya prediksi kadar patchouli alkohol berdasarkan spektrum mentah atau Non Pretreatment dapat dilihat pada Gambar 3.

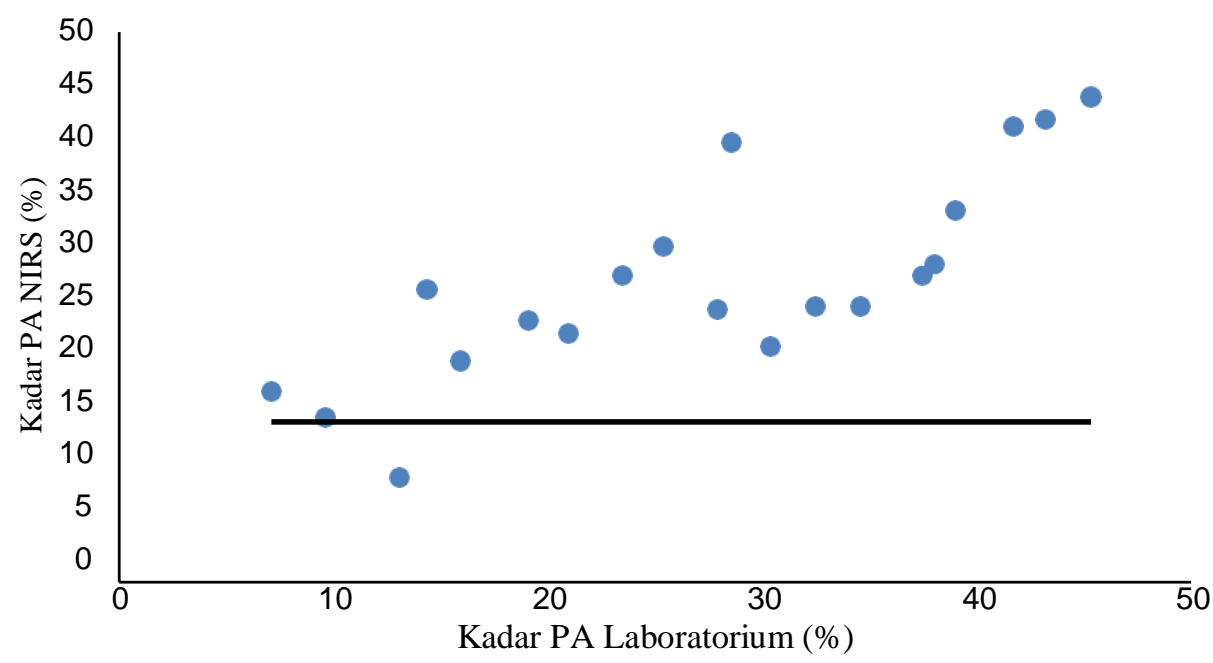

Gambar 3. Plot Data Kalibrasi Kadar Patchouli Alkohol Pada Non Pretreatment

\section{Pendugaan Kadar Patchouli Alkohol Minyak Nilam Menggunakan PLS dan Pretreatment De-trending}

Perlakuan data dengan menggunakan Pretreatment De-trending mampu menghapus tren nonlinear pada data spektrum. Gambar 4 menunjukkan spektrum minyak nilam yang diberikan Pretreatment De-trending terlihat tipikal spektrum berubah dan noise spektrum berkurang yang ditandai dengan spektrum tampak lebih rapat dibandingkan spektrum mentah.

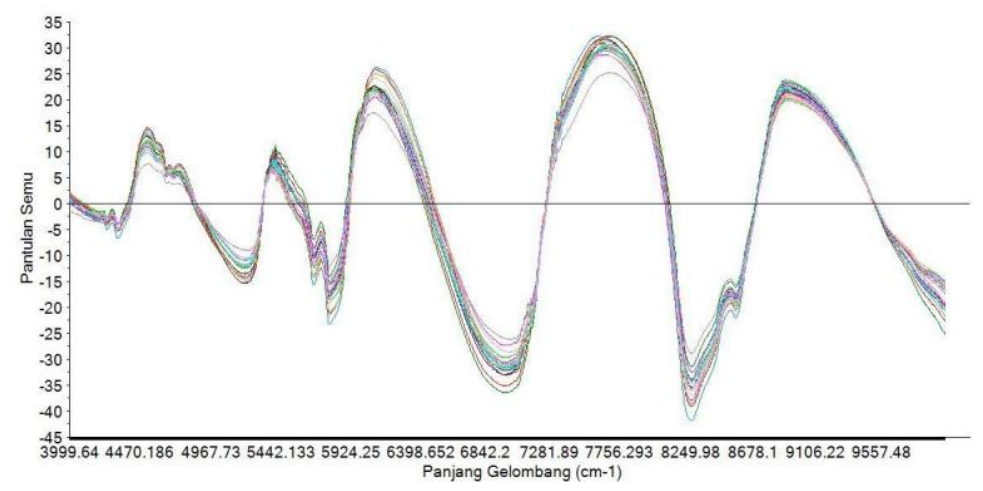

Gambar 4. Spektrum Minyak Nilam dengan Pretreatment De-trending

Pada pretreatment de-trending didapatkan nilai koefisien korelasi (r) sebesar 0,90. 
Menurut Safitri (2016), apabila nilai koefisien korelasi (r) yang didapatkan 0,90 maka tergolong hubungan sangat kuat. Nilai koefisien korelasi meningkat setelah diberikan pretreatment dari 0,79 menjadi 0,90 . Nilai koefisien determinasi $\left(R^{2}\right)$ yang didapatkan sebesar 0,82 . Menurut Karoui et al. (2006) apabila nilai koefisien determinasi $\left(\mathrm{R}^{2}\right)$ yang didapatkan 0,82 menunjukkan prediksi yang baik. Nilai koefisien determinasi meningkat setelah diberikan pretreatment dari 0,63 menjadi 0,82 . Nilai root mean square error calibration (RMSEC) yang didapatkan sebesar 4,74 lebih rendah dari nilai standar deviasi dan latent variable yang digunakan adalah 4. Menurut Zulfahrizal et al. (2020) apabila nilai RMSEC lebih kecil dari standar deviasi bearti data tergolong bagus dan nilai latent variable yang baik yaitu dibawah 9. Nilai RMSEC menurun setelah diberikan pretreatment dari 6,90 menjadi 4,75. Nilai residual predictive deviation (RPD) yang didapatkan adalah 2,45. Menurut Nicolai et al. (2007) apabila nilai RPD yang didapatkan 2,45 maka digolongkan dalam prediksi yang baik (good performance). Nilai residual predictive deviation (RPD) meningkat setelah diberikan pretreatment dari 1,68 menjadi 2,45. Plot data kalibrasi pada pretreatment de-trending dapat dilihat pada Gambar 5.

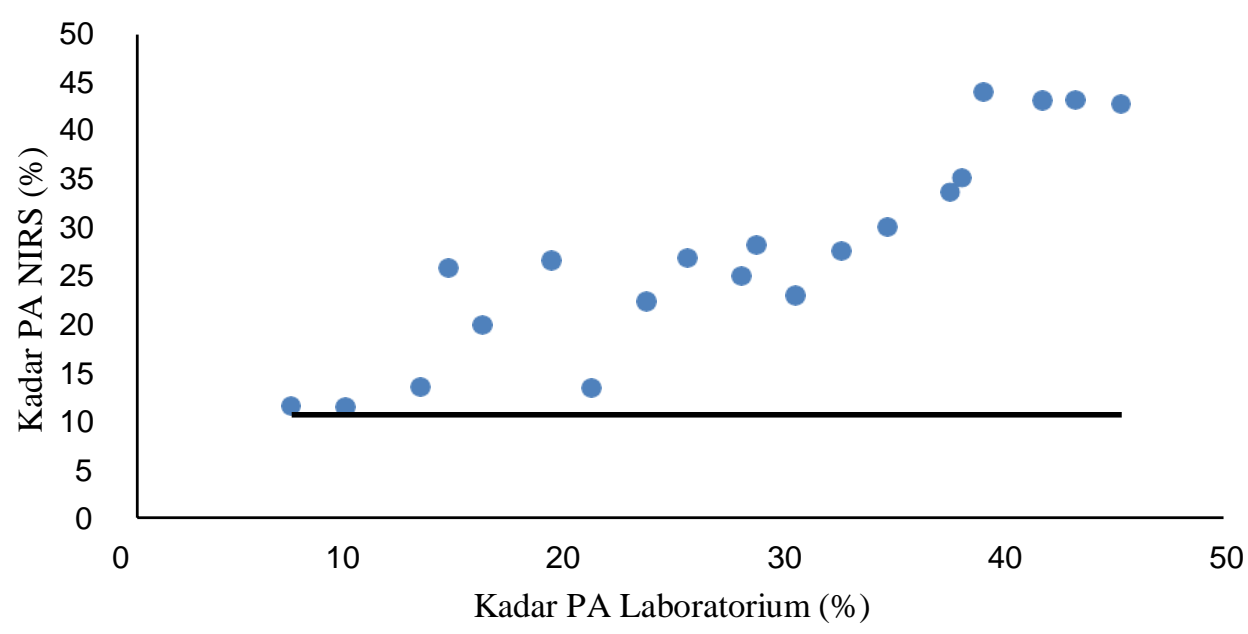

Gambar 5. Plot Data Kalibrasi Kadar Patchouli Alkohol Pada De-trending

\section{Pendugaan Kadar Patchouli Alkohol Minyak Nilam Menggunakan PLS dan Pretreatment Standart Normal Variate}

Penggunaan pretreatment standart normal variate (SNV) ini bertujuan untuk mengurangi pengaruh interferensi gelombang (noise). Penggunaan pretreatment standart normal variate (SNV) berhasil menghilangkan scatter effects (penyebaran efek) dari spektrum, sehingga spekrum minyak nilam yang dihasilkan tampak lebih bagus. Dapat dilihat pada Gambar 6 spektrum minyak nilam menggunakan pretreatment standart normal variate (SNV) yang telah mampu menghilangkan noise pada spktrum ditandai dengan spektrum yang tampak lebih rapat.

Hasil pendugaan pada pretreatment standart normal variate memberikan nilai koefisien korelasi (r) sebesar 0,93. Menurut Safitri (2016) apabila nilai koefisien korelasi (r) yang didapatkan 0,93 menunjukkan korelasi sempurna atau hubungan sangat erat. Nilai koefisien korelasi meningkat setelah diberikan pretreatment dari 0,79 menjadi 0,93 . Nilai koefisien determinasi $\left(\mathrm{R}^{2}\right)$ yang didapatkan sebesar 0,86. Menurut Karoui et al. (2006) apabila nilai koefisien determinasi yang didapatkan 0,93 menunjukkan bahwa prediksi yang dihasilkan merupakan prediksi yang sangat baik. Nilai koefisien determinasi meningkat setelah diberikan pretreatment dari 0,63 menjadi 0,93. Nilai root mean mean square error calibration (RMSEC) 
yang didapatkan sebesar 4,11 lebih kecil dari nilai standar deviasi dan latent variable yang digunakan adalah 4. Menurut Zulfahrizal et al. (2020) apabila nilai RMSEC lebih kecil dari standar deviasi bearti data tergolong bagus dan nilai latent variable yang baik yaitu dibawah 9 . Nilai RMSEC menurun setelah diberikan pretreatment dari 6,90 menjadi 4,11. Nilai residual predictive deviation (RPD) yang didapatkan adalah 2,83. Menurut Nicolai et al. (2007) apabila nilai RPD yang didapatkan 2,83 maka digolongkan dalam prediksi yang baik (good performance). Nilai residual predictive deviation (RPD) meningkat setelah diberikan pretreatment dari 1,68 menjadi 2,83. Plot data kalibrasi pretreatment standart normal variate dapat dilihat pada Gambar 7.

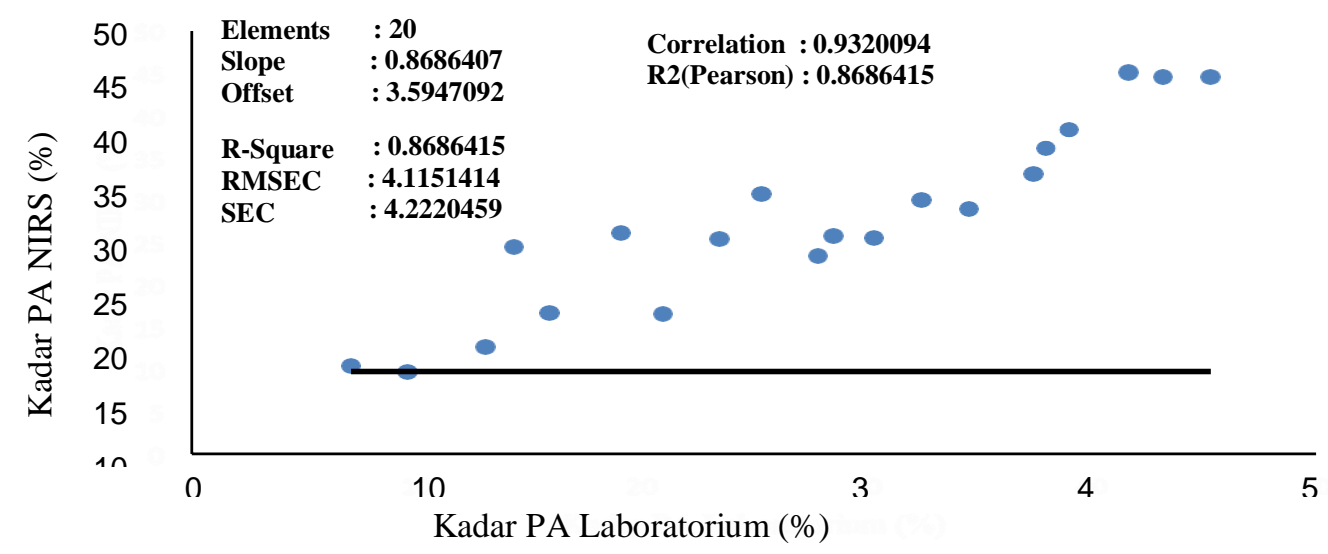

Gambar 6. Spektrum Minyak Nilam dengan Pretreatment Standart Normal Variate

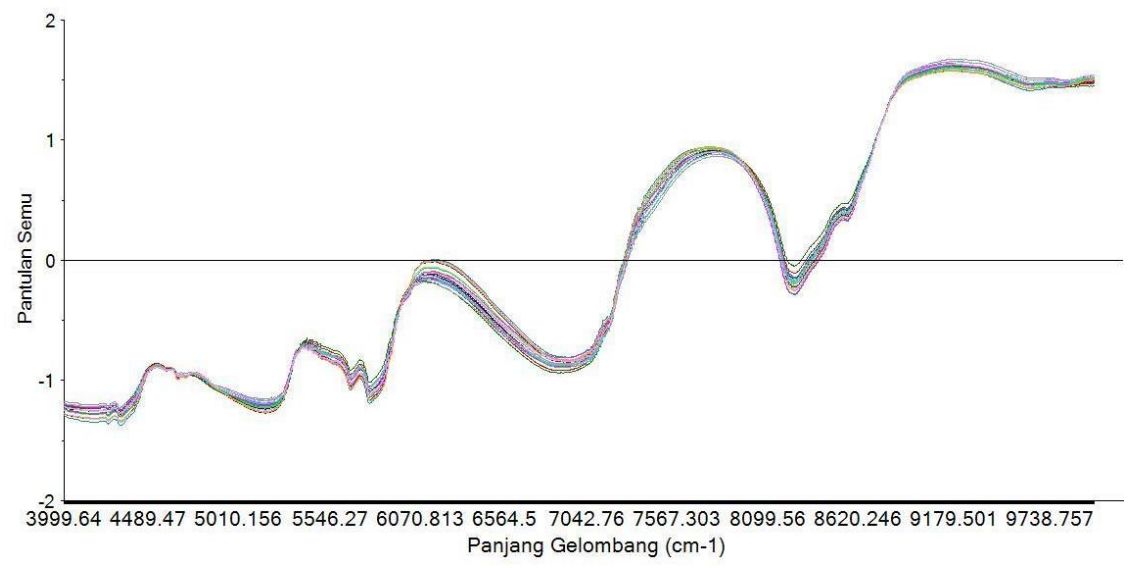

Gambar 7. Plot Data Kalibrasi Kadar Patchouli Alkohol Pada Standard Normal Variate

\section{Model Terbaik untuk Prediksi Patchouli Alkohol Minyak Nilam}

Penentuan model terbaik pendugaan kadar patchouli alkohol minyak nilam dengan teknologi near infrared reflectance (NIR) dengan melihat nilai latent variable, koefisien determinasi $\left(\mathrm{R}^{2}\right)$, koefisisen korelasi $(\mathrm{r})$, root mean square error calibration (RMSEC) dan menghitung nilai residual predictive deviation (RPD) sebagai interpretasi dari pengembangan model kalibrasi. Nilai residual predictive deviation (RPD) dapat dihitung dengan cara membagi nilai standar deviasi dengan nilai root mean square error calibration pada masing-masing prediksi kadar patchouli alkohol pada tahap pengembangan model kalibrasi. Interpretasi pengembangan model kalibrasi partial least square (PLS) pada pendugaan kadar patchouli 
alkohol minyak nilam menggunakan near infrared reflectance spectroscopy (NIRS) pada spektrum non pretreatment dan dengan pretreatment dapat dilihat pada Tabel 2.

Tabel 2. Hasil Interpretasi Pengembangan Model Kalibrasi Partial Least Square

\begin{tabular}{lccccc}
\hline Pendugaan & Latent Variable & $\mathrm{r}$ & $\mathrm{R}^{2}$ & $\begin{array}{c}\text { RMSEC } \\
(\%)\end{array}$ & $\mathrm{RPD}$ \\
\hline Non pretreatment & 4 & 0,79 & 0,6 & 6,90 & 1,68 \\
$\begin{array}{l}\text { De-trending } \\
\text { Standart Normal }\end{array}$ & 4 & 0,90 & 0,8 & 4,75 & 2,45 \\
Variate & 4 & 0,93 & 0,8 & 4,11 & 2,83 \\
\hline
\end{tabular}

Berdasarkan Tabel 2 dapat dilihat bahwa nilai koefisien korelasi (r) pada pretreatment standart normal variate didapatkan lebih baik karena nilai koefisien korelasi (r) sebesar 0,93 lebih besar dibandingkan dengan yang lain. Selanjutnya nilai koefisien determinasi $\left(\mathrm{R}^{2}\right)$ yang didapatkan yaitu sebesar 0,86 pada pretreatment standart normal variate maka lebih baik karena nilai koefisien korelasi (r) sebesar 0,86 paling besar dibandingkan dengan yang lain. Nilai root mean square error calibration (RMSEC) yang didapatkan oleh pretreatment standart normal variate yaitu sebesar 4,11 lebih baik karena nilai yang didapatkan paling kecil dibandingkan dengan yang lain. Kemudian berdasarkan nilai residual predictive deviation (RPD) untuk pretreatment standart normal variate didapatkan nilai sebesar 2,83 lebih baik karena nilai yang didapatkan lebih besar dibandingkan dengan pretreatment yang lain. Berdasarkan semua pembahasan dapat disimpulkan bahwa pretreatment terbaik yang digunakan untuk prediksi kadar patchouli alkohol pada minyak nilam menggunakan near infrared reflectance spectroscopy (NIRS) dengan metode partial least square (PLS) adalah pretreatment standart normal variate.

\section{SIMPULAN DAN SARAN}

\section{Simpulan}

Simpulan yang dapat diambil adalah

1. Aplikasi teknologi near infrared reflectance spectroscopy (NIRS) dengan metode partial least square (PLS) dapat memprediksi kadar patchouli alkohol minyak nilam.

2. Model pendugaan prediksi patchouli alkohol yang terbaik pada penelitian ini adalah PLS yang dikombinasikan dengan pretreatment standart normal variate (SNV) dengan latent variable 4, nilai residual predictive deviation (RPD) sebesar 2,83, nilai koefisien determinasi $\left(\mathrm{R}^{2}\right)$ sebesar 0,86, nilai koefisien korelasi ( $\mathrm{r}$ ) sebesar 0,93, nilai root mean square error calibration (RMSEC) sebesar 4,11.

\section{Saran}

Adapun saran yang dapat diberikan adalah perlunya penelitian lanjutan untuk meningkatkan prediksi pendugaan kadar patchouli alkohol ke taraf 99\% dengan kombinasi pretreatment yang lain.

\section{DAFTAR PUSTAKA}

Abdurahman, N. H. dan S. Sundarajan. 2019. Chemical Compound Characterizations of Patchouli Leaf Extract via GC-MS, LC-QTOF-MS, FTIR and 1H NMR. International Journal of Engineering Research and Technology. 8 : 1054-1059. 
Burahman, F. 2020. Pendugaan Kadar Patchouli Alkohol Pada Minyak Nilam Hasil Fraksinasi Menggunakan Metode Principal Component Regression. Skripsi. Program Studi Teknik Pertanian. Fakultas Pertanian Universitas Syiah Kuala. Banda Aceh.

Cen, H dan Y. He. 2007. Theory and Application of Near Infrared Reflectance Spectroscopy in Determination of Food Quality. J. Trends in Food Sci and Technol. 18 : 72-83.

Cozzolino, D., W. U. Cynkar, N. Shah, P. Smith. 2011. Multivariate Data Analysis Using Appliedto Spectroscopy : Potential Application to Juice and Fruit Quality. Food Research International. $44: 1888-1896$.

Darmapatni, A. K., A. Basori, dan Suaniti, N. M. 2016. Pengembangan Metode GCMS untuk Penetapan Kadar Acetaminophen Pada Spesimen Rambut Manusia. Jurnal Biosains Pascasarjana. 18 (3) : 255-269.

Idris, A., Ramajura, M., dan I. Said. 2014. Analisis Kualitas Minyak Nilam (Pogostemon Cablin Benth) Produksi Kabupaten Buol. Jurnal Akademika Kimia, 3 (2) : 79-85.

Karoui, R., A. M. Mouzena, E. Dufourb, L. Pilllonelc, E. Schallerd, J. De Baerdamaekera, J. O. Bossetc. 2006. Chemical Characterisation of Uropean Emmental Cheese by Near Infrared Spectroscopy Using Chemometric Tools. International Dairy Journal. 16 : 1211-1217.

Khalid, Z., A. A. Munawar, H. Meilina. 2017. Pengembangan Produk Minyak Nilam Dalam Upaya Memenuhi Standar Quality Patchouli Alcohol Menggunakan Chemometric. Jurnal Serambi Engineering. 1 (2) : 7.

Mouazen, A. M., W. Saeys, J. Xing, J. D. Baerdemaeker, H. Ramon. 2010. Near Infrared Spectroscopy for Agricultural Materials: An Instrument Comparison. J Near InfraredSpectrosc. $13: 87-97$.

Nicolai, B. M., K. Beullens, E. Bobelyn, A. Peirs, W. Saeys, K.I. Theron, J. Lamertyn. 2007. Non Destructive Measturement of Fruit and Vegetable Quality by Means of NIR Spectroscopy: A Review. Postharvest Biology and Technology. 46 : 99-118.

Nurhasanah. 2018. Prediksi Kadar Air Beras Menggunakan NIRS Dengan Metode PLS (Partial Least Square) dan Pretreatment Standard Normal Variate, Derivative-1, Savitzky Golay Smoothing. Skripsi. Program Studi Teknik Pertanian. Fakultas Pertanian Universitas Syiah Kuala. Banda Aceh.

Safitri, W. R. 2016. Pearson Correlation Analysis to Determine The relationship Between City Population Density with Incident Dengue Fever of Surabaya in The Year 2012-2014.

Scientific Journal of Nursing. 2 (2) : 21 - 29.

Sastrohamidjojo, H. 2002. Kimia Minyak Atsiri. Yogyakarta: FMIPA UGM. Jurnal Teknik ITS. 1 : 25-29.

Syauqiah, I. 2008. Analisis Pengaruh Lama Penyulingan dan Komposisi Bahan Baku Terhadap Rendemen dan Mutu Minyak Atsiri dari Daun dan Batang Nilam. Banjamasin. Universitas Lambung Mangkurat.

Zulfahrizal, A. A. Munawar, dan H. Meilina. 2017. Rancang Bangun Alat Sensor Portable Berbasis Pengembangan Aplikasi Teknologi Near Infrared Sebagai Metode Baru yang Rapid dan Non-Destructive untuk prediksi Kualitas Kakao. Dalam Suhendrayatna, H. Meilina, Zulfahrizal, Sugianto, T. Rikhayat, Jamil, M. Makky dan

A. G. Haji (Eds.) Prosiding Seminar Nasional Pasca Sarjana Universias Syiah Kuala. A32A37.

Zulfahrizal, A. A. Munawar, H. Meilina. 2019. Fast Quantitative Prediction of Patchouli Alcohol Content Using Near Infrared Reflektance Spectroscopy. $2^{\text {nd }}$ International Conference of Essential Oils. Banda Aceh. 29- 30 Oktobel 2019.

Zulfahrizal, A. A. Munawar, Mahlinda. 2020. Desain Alat Sensor Near Infrared Reflectance Spectroscopy untuk Peningkatan Nilai Jual Minyak Nilam Aceh. Laporan Penelitian. Fakultas Pertanian Universitas Syiah Kuala. Banda Aceh. 